Revista Brasileira de Cartografia

ISSN 1808-0936 | https://doi.org/10.14393/revbrascartogr

Sociedade Brasileira de Cartografia, Geodésia, Fotogrametria e Sensoriamento Remoto

\title{
Coastal Vulnerability Index revisited: a case study from Maricá, RJ, Brazil
}

\section{Coastal Vulnerability Index revisto: estudo de caso para Maricá, RJ, Brasil}

\author{
Paulo Renato Gomes Osilieri ${ }^{1}$, José Carlos Sícoli Seoane ${ }^{2}$ e Fábio Ferreira Dias ${ }^{3}$
}

1 Universidade Federal do Rio de Janeiro, Departamento de Geologia, Rio de Janeiro, Brasil. E-mail: pauloosilieri@id.uff.br ORCID: https://orcid.org/0000-0002-6081-8870

2 Universidade Federal do Rio de Janeiro, Departamento de Geologia, Rio de Janeiro, Brasil. E-mail: cainho.geo@gmail.com ORCID: https://orcid.org/0000-0001-7728-3764

3 Universidade Federal Fluminense, Departamento de Análise Geoambiental, Niterói, Brasil. E-mail: fabiofgeo@ yahoo.com.br ORCID: https://orcid.org/0000-0003-2078-7405

\begin{abstract}
The Brazilian coast is over 7000 kilometers long with many different ecosystems. Among these, are the beaches, dominated by the high dynamism caused by the action of oceanographic agents (tides, waves and currents). Human occupation of the coast for living, and the economic use of the coast (ports, tourism, fishing), increase the possibility of damaging this ecosystem. Coastal vulnerability studies are an important tool for the management of these areas, predicting how an environment can cope or recover from extreme events, for example, the rising sea level. This study aims to improve vulnerability evaluation of coastal areas, contributing to a more efficient, accountable and sustainable coastal management. To test the concept, an area at coastal Maricá, a municipality in Rio de Janeiro State, Brazil, was used. This coastline is comprised of a long sandy beach limited by rocky coastal shores. A vulnerability index was calculated from GIS data analysis of geomorphology, coastal slope, shoreline migration, tidal range, maximum height of the waves, sea level change scenario evaluation, dune height, and urban density variables for the various coastline sectors. About a third (34.69\%) of the coasts have very high vulnerability, while have $34.03 \%$ high vulnerability, $25.33 \%$ have moderate and $5.95 \%$ have low vulnerability. Results obtained contribute to the planning and management of the study area, providing a tool for local environmental analysis, and establish a ranking of priorities for public action, based on different levels of vulnerability found to shoreline of Maricá.
\end{abstract}

Keywords: Coastal geomorphology. Coastal management. Geotechnology.

Resumo: A costa brasileira tem mais de 7000 quilômetros de extensão com muitos ecossistemas diferentes. Entre eles, estão as praias, dominadas pelo alto dinamismo causado pela ação dos agentes oceanográficos (marés, ondas e correntes). A ocupação humana do litoral para moradia e o uso econômico (portos, turismo, pesca), aumentam a possibilidade de danificar esse ecossistema. Os estudos de vulnerabilidade costeira são uma ferramenta importante para o gerenciamento dessas áreas, prevendo como um ambiente pode lidar ou se recuperar de eventos extremos, por exemplo, o aumento do nível do mar. Este estudo visa melhorar a avaliação da vulnerabilidade das áreas costeiras, contribuindo para uma gestão costeira mais eficiente, responsável e sustentável. Para testar o conceito, foi utilizada uma área no litoral de Maricá, município do Estado do Rio de Janeiro, Brasil. Este litoral é composto por uma longa praia arenosa limitada por costões rochosos. Um índice de vulnerabilidade foi calculado a partir da análise dentro de um SIG dos dados de geomorfologia, declividade costeira, migração da linha de costa, amplitude das marés, altura máxima das ondas, avaliação do cenário de mudança do nível do mar, altura das dunas e variáveis de densidade urbana para os vários setores costeiros. Foi constatado que 34,69\% do litoral possui vulnerabilidade muito alta, 34,03\% alta, $25,33 \%$ moderada e 5,95\% baixa. Os resultados obtidos contribuem para o planejamento e gestão da área de estudo, fornecendo uma ferramenta para a análise ambiental local, e estabelece um ranking de prioridades para a ação pública, baseado nos diferentes níveis de vulnerabilidade encontrados no litoral de Maricá.

Palavras-chave: Geomorfologia costeira. Gerenciamento costeiro. Geotecnologia. 


\section{INTRODUCTION}

The Brazilian coastal zone is very extensive and heterogeneous, with many different ecosystems. Among these, are the beaches, dominated by the high dynamism caused by the action of oceanographic agents (tides, waves and currents). Human occupation of the coast for living, and the economic use of the coast (ports, tourism, fishing), increase the possibility of damaging this ecosystem.

Coastal vulnerability studies are an important tool for the management of these areas, predicting how an environment can cope or recover from extreme events, for example, the rising sea level. The concept of vulnerability addresses possible impacts and consequences that a particular environment would suffer under an extreme event, and involves an integrated analysis of social, economic and natural factors (ZOU; THOMALLA, 2008; IPCC, 2007; DOLAN; WALKER, 2003; FRAZIER et al., 2010). However, there are studies that concentrate on estimating vulnerability through a more physical bias, using geological, geomorphological and oceanographic parameters (ABUODHA; WOODROFFE, 2006; MUSEKIWA et al., 2015; SZLAFSZTEIN; STERR, 2007, PALMER et al., 2011; TRAN et al., 2010; DEVOY, 2008). This dichotomy between physical and human aspects hinders the definition of a standard methodology, and an individual approach of each study area should be designed, trying to prioritize the main demands of each environment: in a coastline that has high populational density, human aspects should have a greater relevance, whereas in a sparsely populated coast, an analysis that prioritizes the physical aspects is preferable.

This study aims to improve vulnerability evaluation of coastal areas, contributing to a more efficient, accountable and sustainable coastal management, by providing such information for planning and improving the maintenance of the coastal zone. To test the concept, an area at coastal Maricá, a municipality in Rio de Janeiro State, Brazil, was used. This coastline is comprised of a long sandy beach limited by rocky coastal shores.

\section{STUDY AREA}

Maricá municipality (Figure 1) is located in the state of Rio de Janeiro and is part of the Greater Rio de Janeiro metropolitan region, with an area of about $360,000 \mathrm{~km}^{2}$. The coastline of the city goes from the western Itaipuaçu beach to the eastern Jaconé beach, having an east-west orientation and two rocky promontories: the Elephant Rock to the west and Ponta Negra to the east. In this study, the coast was limited only between two rocky headlands, or the beach Itaipuaçu to Ponta Negra.

The geology of Maricá has great chronological variation because of the Proterozoic ages of Ponta Negra and Elephant rocks, compared with the coastal Quaternary deposits.

Silva and Dehler (2001) described the Ponta Negra geology as composed of Búzios Complex paragneiss, dating from the Neoproterozoic / Cambrian, associated with the final Brasiliano collage in the region, related to the Búzios orogeny. According to Silva et al. (2001), Elephant Rock is part of the Cassorotiba Granite, formed during the Cambrian associated with the post-tectonic magmatism period of the Brasiliano Orogen. Over the coastal arc of the municipality are Quaternary deposits of Pleistocene and Holocene age. Caruso Jr., Cunha and Dias (2001) characterize them as marine beach and / or lagoon deposits, aeolian deposits, tidal lagoon deposits and colluvial-alluvial deposits.

Geomorphologicaly, Maricá is part of the South Coast of the state of Rio de Janeiro, or of the Beach Ridge compartment corresponding to Região dos Lagos of Muehe and Valentini (1998).

\section{MATERIALS AND METHODS}

Coastal vulnerability encompasses the identification, correlation and analysis of diverse data of physical and human variables. All this is expressed as a Coastal Vulnerability Index (CVI), which represents a mathematical relationship. As a basis for this study we used the index proposed by Thieller and Hamar-Klose (1999), which calculates the coastal vulnerability through six physical variables: tidal range, significant wave height, shore slope, coastal geomorphology, line variation coast and sea level change rate. This calculation was modified to better suit the study area and its characteristics (Table 1). Each variable used is described in 
detail below.

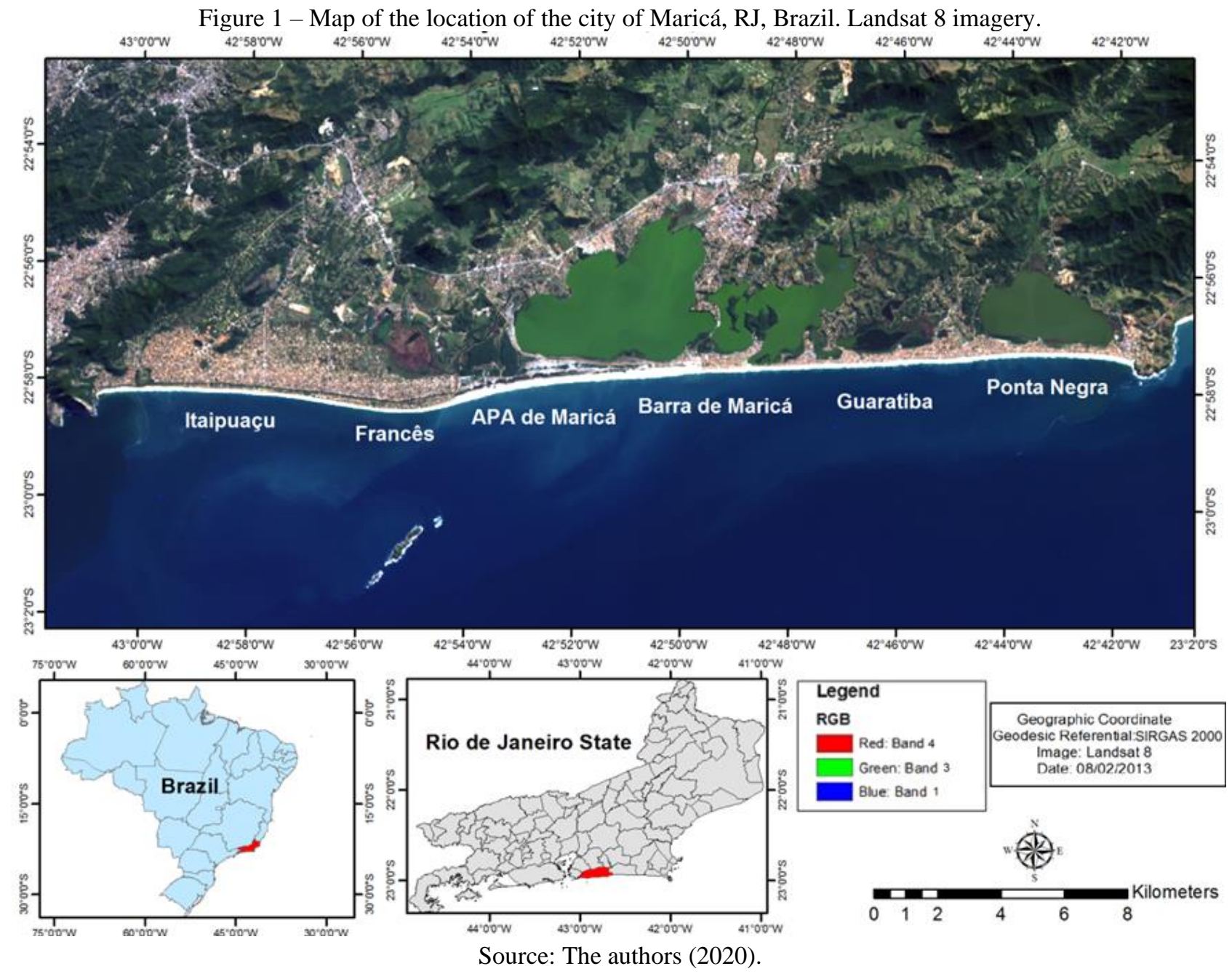

Table 1 - Comparison of the present work method to that of Thieller and Hamar-Klose (1999).

\begin{tabular}{c|c}
\hline Thieller and Hamar-Klose (1999) & Proposed method \\
\hline Geomorphology & Geomorphology \\
\hline Coastal slope & Coastal slope \\
\hline Mean tide range & Mean tide range \\
\hline Sea-level change & Sea-level change \\
\hline Shoreline erosion/accretion & Shoreline erosion/accretion \\
\hline Maximum wave height & Maximum wave height \\
\hline- & Dune height \\
\hline- & Urban Density \\
\hline
\end{tabular}

Source: The authors (2020).

\subsection{Geomorphology}

This takes into account the possibility of a given site being eroded and / or impacted by rising sea levels. This variable is taken from literature already published for the study area (such as SILVA; SILVA; SANTOS, 2008; SILVA; ABREU; SILVESTRE, 2012; LINS-DE-BARROS, 2005), as well as from visual analysis of features during fieldwork, satellite image and aerial photograph photointerpretation, and finally from the correlation with altimetry data from a digital terrain model generated from Project RJ - 25 data (IBGE, 2005, in 1:25,000 scale). Geomorphological classes were defined based on the work of Thieller and HamarKlose (1999). 


\subsection{Coastal slope}

Coastal slope is used to model the space and the time of flooding. The lower the slope the faster the retreat of the coastline in relation to the rising sea level (PILKEY; DAVIS, 1987). The value of this variable is calculated from the slope obtained from the slope tool, available in ArcGIS 10.1 software, using data from the same digital terrain model mentioned above (IBGE, 2005), fused to Nautical Chart 1506, scale 1: 75,000, available from the website of the Directorate of Hydrography and Navigation of the Brazilian Navy (DHN). Despite the difference in scale, the nautical chart in question was used as it is the only publicly available bathymetric data. An average slope of the coastal stretches is calculated, from the statistics generated for each sector, which are based on the topographic ridges that divide the basins.

The numerical values for each slope class were reclassified in order to better understand the local geomorphology. Thus, the slope classification proposed by EMBRAPA (1999) was used, adapted to five vulnerability classes (Table 2 ).

Table 2 - Coastal slope steepness classes used for the coastal vulnerability index. Source: adapted from Embrapa

\begin{tabular}{c|c|c}
\hline \multicolumn{3}{|c}{ (1999). } \\
\hline Coastal slope (\%) & Terrain type & Coastal vulnerability \\
\hline $0-3$ & Flat & Very high \\
\hline $3-8$ & Mildly Undulating & Moderate \\
\hline $8-20$ & Undulating & Low \\
\hline $20-45$ & Strongly Undulating & Very low \\
\hline $45-75$ & Mountainous &
\end{tabular}

Source: Adapted from Embrapa (1999).

The difference between the reduction level of the Navy (RL, bathymetry) and the Sea Level of IBGE maps (SL, altimetry) were corrected in order to minimize errors at the ever important coastline. The result is $68.8 \mathrm{~cm}$, which is added to the bathymetry data (Figure 2).

Figure 2 - Difference between RL (Navy of Brazil) and SL (IBGE).

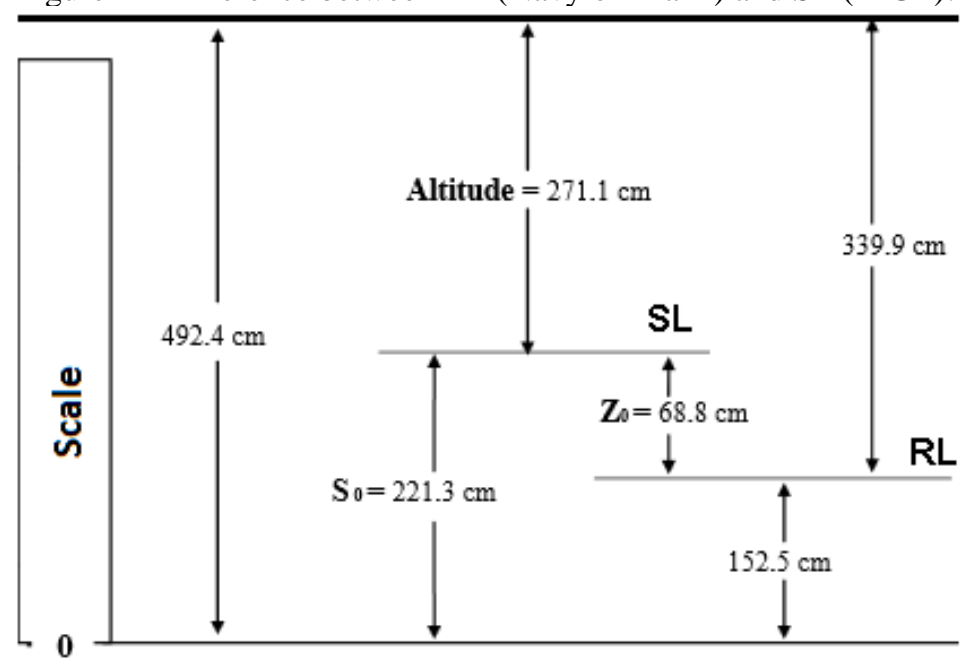

Source: Adapted from tide station 50140 of Navy of Brazil (2010).

\subsection{Sea - level change}

Relates to the power of permanent inundation of the coastal system. IPCC (2007) data were used (Table 3) for the quantification of vulnerability, based on the classification of Thieller and Hamar-Klose (1999). The choice of IPCC data is due to its official status as the UN study on global climate change.

\subsection{Shoreline change}

Concerns the shortest time necessary to identify geological / geomorphological changes on the coast. 
Coastline was interpreted for two moments, based on two mosaics of aerial photographs. The first group of photos consists of images from the Brazilian Air Force (FAB) and date from July 1976, at 1: 20,000 scale. The second group comprises images from the Brazilian Institute of Geography and Statistics (IBGE) from July 2005, at 1: 25,000 scale. The photographs were georeferenced in a Geographic Information System (GIS) for manual vectorization of the beach lines needed for comparison. Control points were collected using geodetic receptors in each coastal compartment to validate the georeferencing. The criterion used to delimit the beach line was the presence of erosion escarpments, which is easily identifiable both at the images and during fieldwork.

Table 3 - Average heating projection surface and the global rise in sea level at the end of the XXI century.

\begin{tabular}{c|c|c|c}
\hline Scenario & \multicolumn{2}{|c|}{ Temperature change $\left({ }^{\mathbf{}} \mathbf{C}\right)$} & Sea-level rise (m) \\
\hline & Best estimate & Likely range & Likely range \\
\hline B1 & 1.8 & $1.1-2.9$ & $0.18-0.38$ \\
\hline A1T & 2.4 & $1.4-3.8$ & $0.20-0.45$ \\
\hline B2 & 2.4 & $1.4-3.8$ & $0.20-0.43$ \\
\hline A1B & 2.8 & $1.7-4.4$ & $0.21-0.48$ \\
\hline A2 & 3.4 & $2.0-5.4$ & $0.23-0.51$ \\
\hline A1FI & 4.0 & $2.4-6.4$ & $0.26-0.59$ \\
\hline
\end{tabular}

Source: Adapted from IPCC (2007).

\subsection{Mean tide range}

Used for identifying a coastal strip that will not be permanently flooded, but that will adapt to the eventual contact with the sea at certain times of day. The data is obtained from coastal tide charts of the Port of Rio de Janeiro (20 km west of the area) and of Forno Port (located in the city of Arraial do Cabo, $70 \mathrm{~km}$ to the east), which are the closest to the study area. These are available on the DHN (Diretoria de Hidrografia e Navegação - Marinha do Brasil) website, and the maximum tide variation from both tide gauges is used as the parameter for calculating CVI.

\subsection{Maximum wave height}

Relates to the power of erosion of the coastal system, since the Maricá coastline is characterized as dominated by waves, thus being the main oceanographic agent of landscape transformation. To accomplish the wave height calculation, data were collected from CPTEC / INPE, based on the global wave model WAVEWATCH III (TOLMAN, 2009) for a period of one year during 2014. Results are presented as graphics of wave height / direction and frequency. Maximum wave height is the variable considered for CVI calculation.

\subsection{Dune height}

Evaluates coastal protection against oceanographic events (abrasion, erosion, overwash) provided by the dune field. Through field observations, altitude collected with GNSS receivers establishes the height of the dunes in the study area and rank them based on the work of Abuodha and Woodroffe (2006), shown in Table 8. A geodetic GPS collects elevation points in different parts of the dune field to quantify the height of aeolian features. The geodetic GPS provides the ellipsoidal height $(\mathrm{h})$, and a calculation is necessary to find the orthometric height $(\mathrm{H})$ by the mathematical relationship shown in Figure 3.

\subsection{Urban Density}

Provides a socio-environmental analysis of space, relating the amount of buildings with the space of the coastal zone, indicating how much each part of the coast has been modified by construction. Private and collective household data is consulted to evaluate this variable. The greater the presence of buildings along the coastline, the higher the vulnerability, since the setting was further modified by changing the ability to protect the coastal front and of recovery from extreme events. Census tracts of the city, from IBGE Digital Municipal 
Mesh Census (2011), imagery, and field observations are the main sources. Satellite imagery (Landsat 8) was acquired free of charge on the website of the USGS (United States Geological Survey).

Figure 3 - Mathematical relationship to obtain the orthometric height.

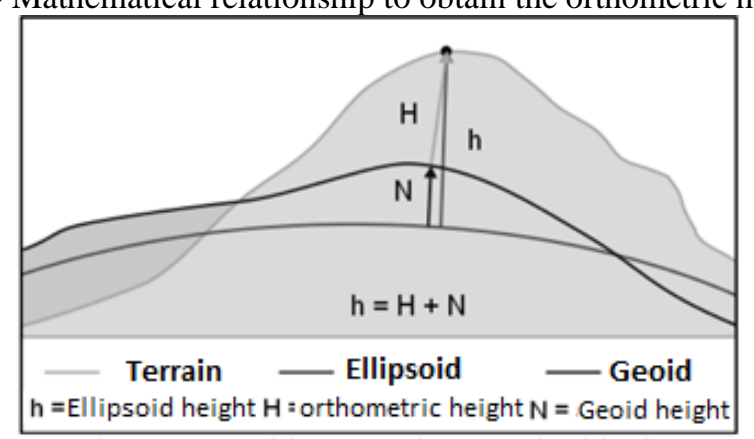

Source: Adapted from IBGE (2015).

The difficulty of establishing a range of values to define the number of buildings for each class makes it necessary to interpret the data qualitatively through photo interpretation and field work. Thus, the classes have been separated in accordance with the interpretation described below (Table 4).

Table 4 - Description of coastal vulnerability classes associated with urban density.

\begin{tabular}{c|c}
\hline Coastal vulnerability & Urban density \\
\hline Very low & No construction \\
\hline Low & Small number of buildings in only part of the coastal profile. \\
\hline Moderate & Small number of buildings distributed throughout the coastal profile. \\
\hline High & $\begin{array}{c}\text { Large number of buildings around the transverse profile of the coast, also presenting } \\
\text { empty spaces between buildings in a significant area to enable urban sprawl. }\end{array}$ \\
\hline Very high & $\begin{array}{c}\text { Large number of buildings around the transverse profile of the coast, without space } \\
\text { between buildings for urban sprawl. }\end{array}$ \\
\hline
\end{tabular}

Source: The authors (2020).

\subsection{Classification of variables}

The variables were classified and quantified into a vulnerability index based on table 5 .

Table 5 - Classification of variables for the coastal vulnerability index.

\begin{tabular}{c|c|c|c|c|c}
\hline Variable & Very low & Low & Moderate & High & Very high \\
\hline Geomorphology & 1 & 2 & 3 & 4 & 5 \\
\hline $\begin{array}{c}\text { Roastal slope } \\
\text { coasts, fiords, } \\
\text { fiards }\end{array}$ & $45-75$ & $\begin{array}{c}\text { Medium cliffs, } \\
\text { indented coasts }\end{array}$ & $\begin{array}{c}\text { Low cliffs, } \\
\text { glacial drift, } \\
\text { alluvial plains }\end{array}$ & $\begin{array}{c}\text { Cobble } \\
\text { beaches, } \\
\text { estuary, lagoon }\end{array}$ & $\begin{array}{c}\text { Barrier beaches, sand beaches, } \\
\text { salt marsh, mud flats, delta, } \\
\text { mangrove, coral reefs }\end{array}$ \\
\hline $\begin{array}{c}\text { Sea-level } \\
\text { change } \\
\text { (mm/year) }\end{array}$ & $<1.8$ & $1.8-2.5$ & $2.5-2.95$ & $2.95-3.16$ & $0-3$ \\
\hline $\begin{array}{c}\text { Shoreline } \\
\text { change (m/year) }\end{array}$ & $>2.0$ & $1.0-2.0$ & $-1.0-(+1.0)$ & $-1.1-(-2.0)$ & $>3.16$ \\
\hline $\begin{array}{c}\text { Mean tide range } \\
(\mathrm{m})\end{array}$ & $>6.0$ & $4.1-6.0$ & $2.0-4.0$ & $1.0-1.9$ & $<(-2.0)$ \\
\hline $\begin{array}{c}\text { Maximum } \\
\text { height wave }(\mathrm{m})\end{array}$ & $<0.55$ & $0.55-0.85$ & $0.85-1.05$ & $1.05-1.25$ & $<1.0$ \\
\hline Dune height $(\mathrm{m})$ & $>30$ & $20.1-30.0$ & $10.1-20.0$ & $5.1-10.0$ & $>1.25$ \\
\hline Urban density & Very low & Low & Moderate & High & $0-5.0$ \\
\hline
\end{tabular}

Source: The authors (2020). 


\subsection{Integration of variables into an index}

After choosing and quantification, variables must be arranged in a mathematical relationship for the CVI. This procedure is quite relative and complicated to carry out, as a quantification of coastal vulnerability is only possible through the interpretation of natural and human constraints of the coastal zone, which does not always have regular behavior over historical and geological time. Therefore, there is no standard and precise formula for determining the CVI. Each study should propose its own index taking into account the particularities of each study area.

In this work we used the equation of the root mean square of the products, as recommended by Gornitz and White (1992).

The Coastal Vulnerability Index (CVI) uses the following equation:

$$
C V I=\sqrt{\frac{x_{1} * x_{2} * x_{3} * x_{4} * x_{5} * x_{6} * x_{7} * x_{8}}{8}}
$$

The variables for the equation are:

$\mathrm{x}_{1}=$ Geomorphology

$\mathrm{x}_{2}=$ Coastal slope

$\mathrm{x}_{3}=$ Sea-level change

$\mathrm{x}_{4}=$ Shoreline change

$\mathrm{x}_{5}=$ Mean tide range

$\mathrm{x}_{6}=$ Maximum height wave

$\mathrm{x}_{7}=$ Dunes height

$\mathrm{x}_{8}=$ Urban density

After calculating the CVI along the coast, basic statistics like average, median and mode are generated for the data. The result is presented as 25,50 and 75 percentiles, as shown in Table 6 .

Table 6 - Distribution of coastal vulnerability results from percentiles.

\begin{tabular}{c|c}
\hline Coastal vulnerability & Percentile \\
\hline Low & $<25$ \\
\hline Moderate & $25-50$ \\
\hline High & $50-75$ \\
\hline Very high & $>75$ \\
\hline
\end{tabular}

Source: The authors (2020).

\section{RESULTS AND DISCUSSIONS}

\subsection{Geomorphology}

The following geomorphological classes were established for the city of Maricá, based on field observations and altimetry data: coastal plain, fluvial-marine plain, island, lagoon, hills, rocky cliff, and fluvial channel (Figure 4).

Thus, for calculating the coastal vulnerability associated with geomorphological criteria, two indices are identified: 1 - Very Low and 5 - Very High. The very low rate is associated with the topographic relief of rocky shores, as this feature is more durable and of greater height, able to withstand extreme events and a possible rise in sea level. The very high index is associated to the sandy beaches and barrier beaches that are located throughout the shoreline studied, as the unconsolidated sediments present greater erodibility. 
Figure 4 - Geomorphological classes identified in Maricá.
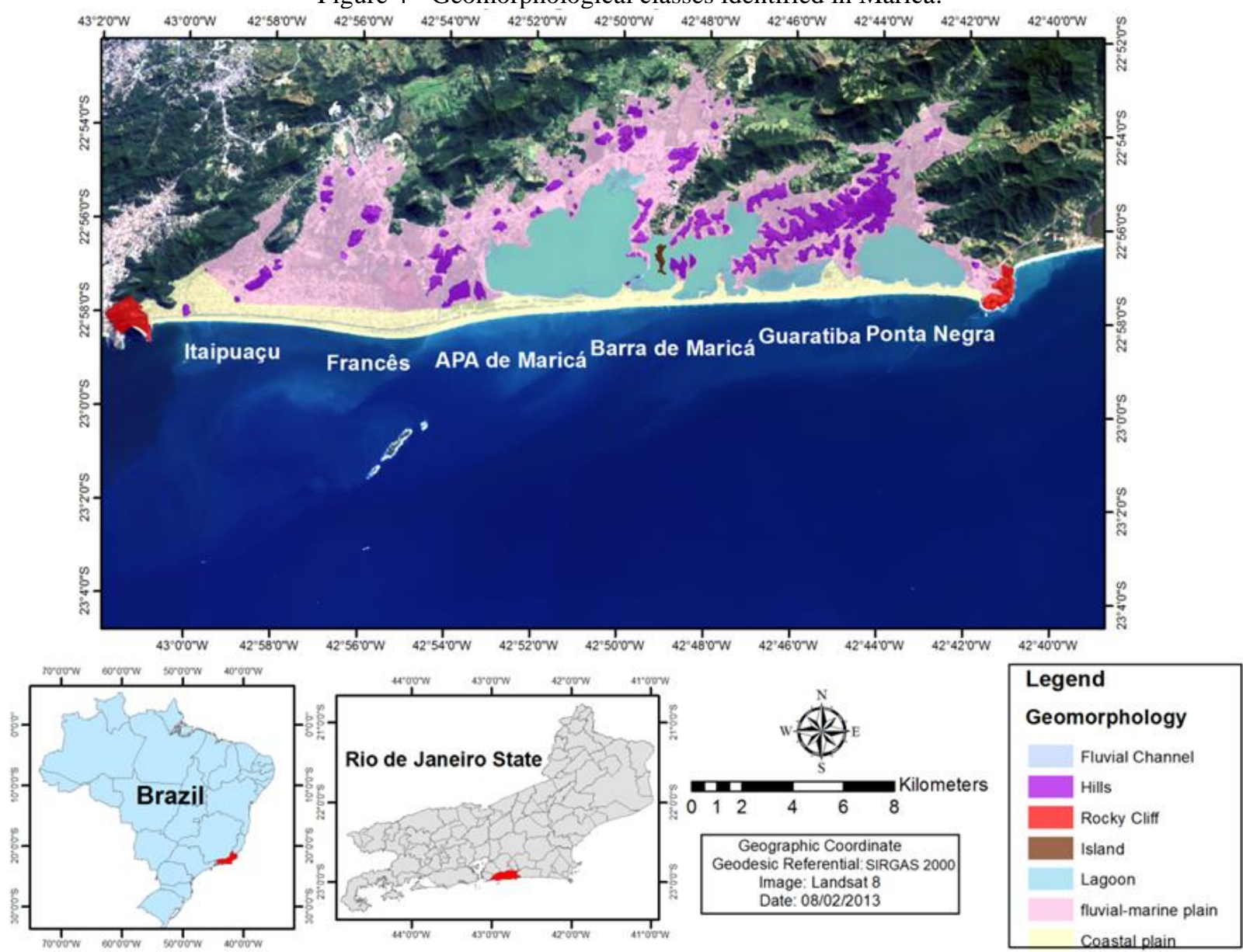

Source: The authors (2020).

\subsection{Coastal slope}

For the analysis of the coast slope, a map was generated through the slope tool, in ArcGIS 10.1 software. Quantification of slope (Table 5) along the coast is based on the average slope of each defined sector (Figure 5). The sectors are not homogeneous, since they are conditioned by local relief features (Figure 6).

Table 5-Average declivity of sectors to Maricá shoreline.

\begin{tabular}{c|c|c}
\hline Sectors & Coastal slope (\%) & Coastal Vulnerability \\
\hline Itaipuaçu 1 & 18.20 & Moderate (CVI 3) \\
\hline Itaipuaçu 2 & 16.04 & Moderate (CVI 3) \\
\hline Francês & 4.62 & High (CVI 4) \\
\hline APA de Maricá & 5.87 & High (CVI 4) \\
\hline Barra & 9.54 & Moderate (CVI 3) \\
\hline Guaratiba & 5.93 & High (CVI 4) \\
\hline Ponta Negra & 12.93 & Moderate (CVI 3)
\end{tabular}

Source: The authors (2020). 
Figure 5 - Maricá county declivity map.

Slope of Maricá, RJ, Brazil.
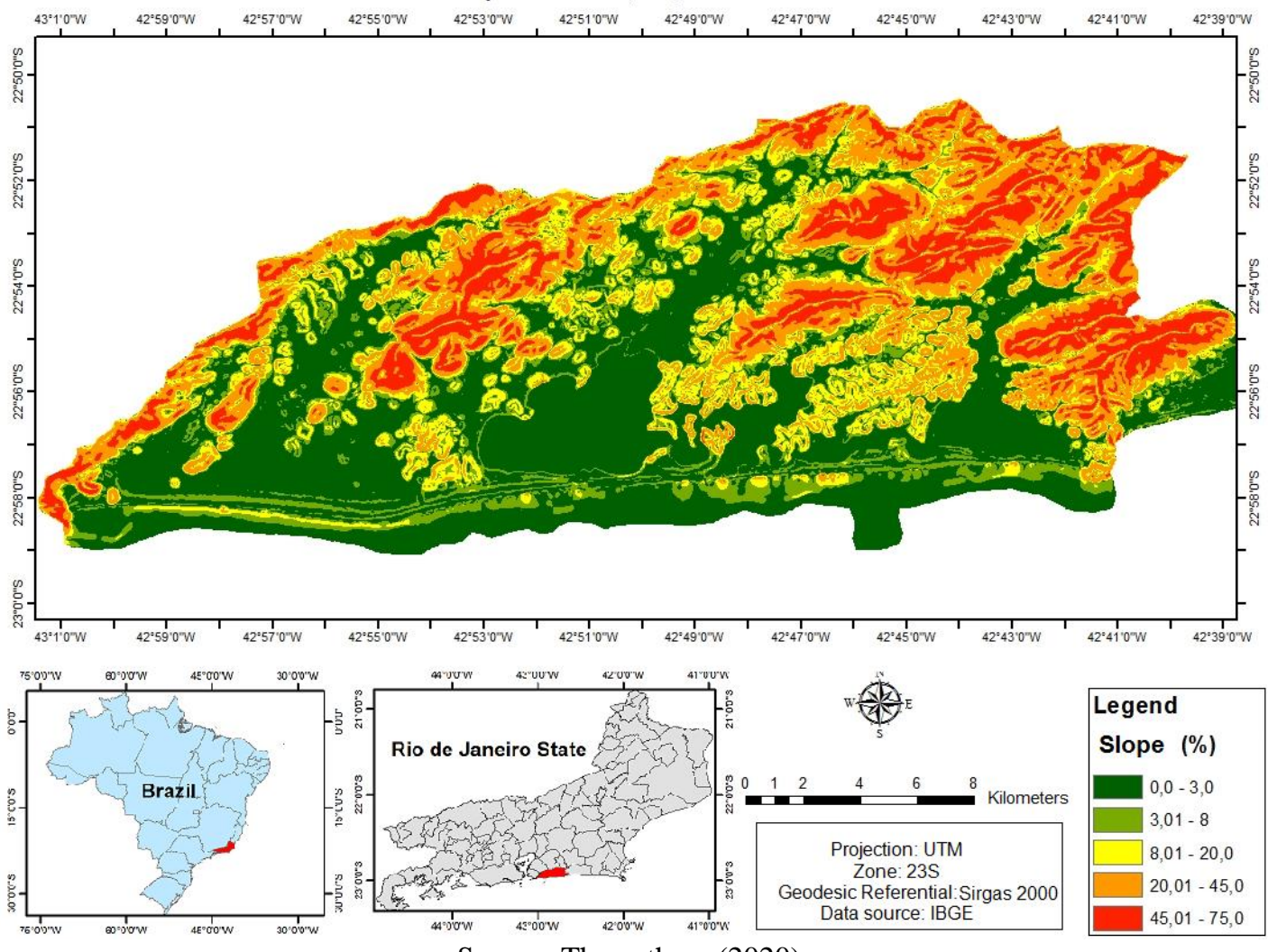

Source: The authors (2020).

Figure 6 - Delimited sectors for calculating the coastal slope.

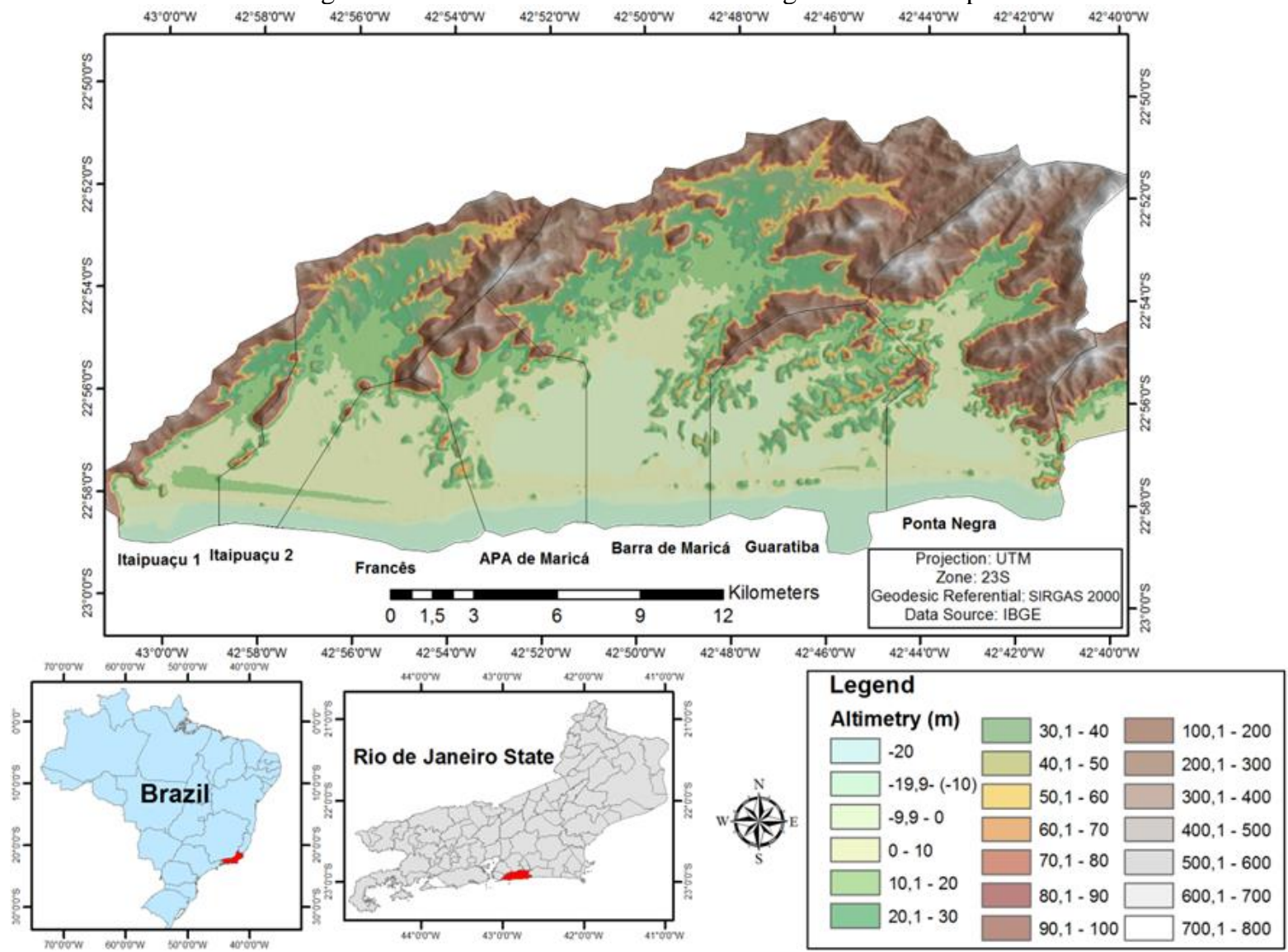

Source: The authors (2020) 
The steepness obtained along the coast falls into a moderate to high vulnerability profile. The mountainous geomorphology of the municipality, in a relatively short distance from the sea, reduces the values of vulnerability, since the higher the less land will be the impacted by extreme events, such as rising sea levels. On the contrary, land portions that have lower altitudes, or where mountainous terrain is farther away, are set as the most vulnerable areas, as they will be more easily affected by changes in climate and oceanographic dynamics.

Thus, the Maricá coast was rated two levels of vulnerability: CVI 3 - Moderate (8-20\%) and CVI 4 $-\operatorname{High}(3-8 \%)$.

\subsection{Sea-level change}

The classification of the coast by potential sea-level variation indicated by IPCC data (2007) yields a very high vulnerability to the coast (CVI 5). However, it is worth noting that such projections are not unanimous in science and that the models used do not necessarily correspond exactly to the future of the planet. Several published papers question the data, interpretations and methods of the IPCC for this theme (PATERSON, 2011; MOLION, 2008). It is also pointed out that the data refers to sea level changes on a global scale, making no distinction of different scenarios along the coastal areas around the world. Based on this interpretation, the rising sea level in the coastal area of Maricá could cause the destruction of houses, streets and other buildings due to flooding. Furthermore, physical structures not affected by extreme events, such as storm waves, would be impacted once the sea would have advanced inward towards the shore; increased salt water intrusion would impact the underground aquifers; beach ridges would tend to migrate landward; marshes would be drowned; and low lands near the beach and on the edge of the lagoon system would be flooded.

In order to refine this analysis it is necessary to use data on a larger scale for the study of the relative sea level.

\subsection{Shoreline change}

Throughout most of the shoreline studied, the rates of change of the coastline indicate a behavior of some stability with alternating positive and negative variations, but with low absolute values, which makes the coast to be rated as vulnerability 3 (Moderate). However, few of the coastal sites showed varying rates slightly more distinct and have been detailed.

The Francês beach sector presents a retreat of over 29 meters, at its western limits with Itaipuaçu, and ranks a high vulnerability index, with an average coastline retreat of over 1 meter per year (Figure 7).

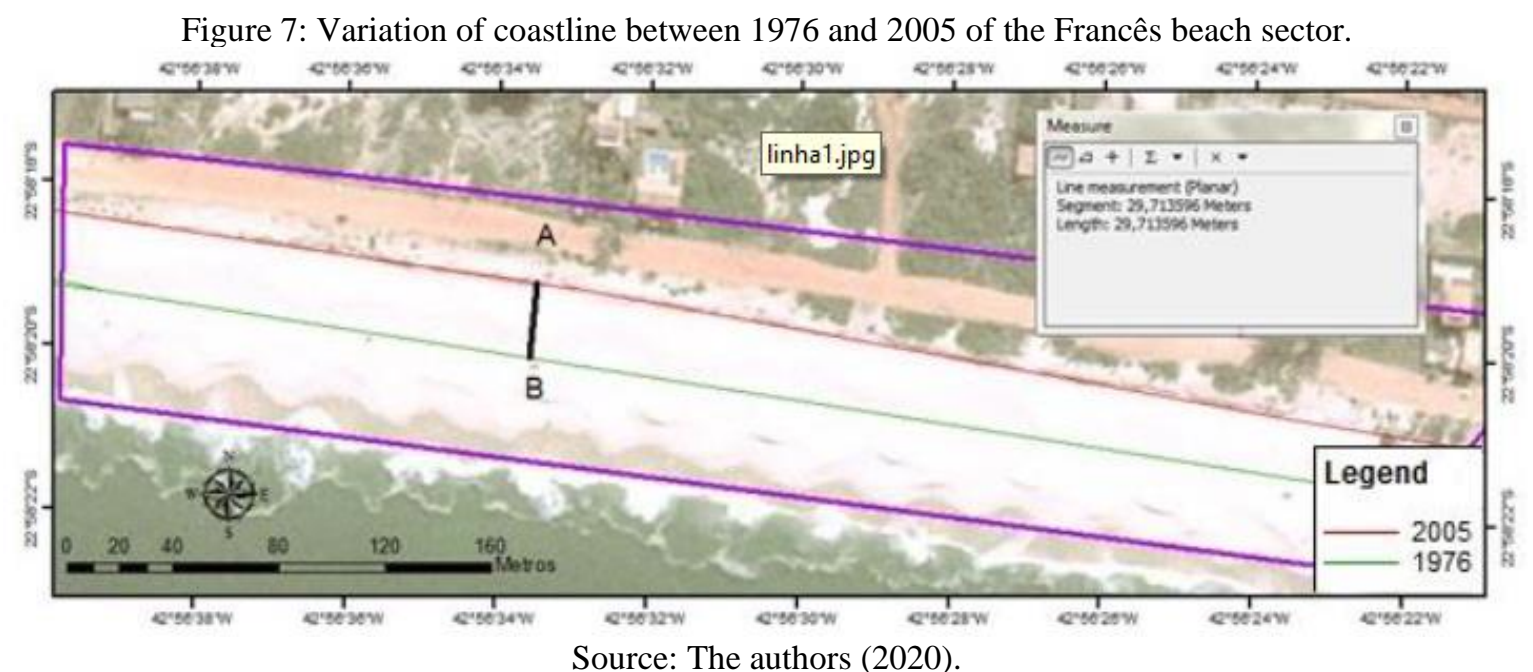


The Itaipuaçu sector has part of its coastline presenting an accretion over 40 meters, being rated as low vulnerability, with an average of progradation above 1.7 meters per year (Figure 8 ). In this sector in particular, Silva, Silva and Santos (2008) state that despite having geological / geomorphological indicators of erosion, the coast is not being eroded. This statement is consistent with the data presented here since, on the coast line analysis, the coastline as a whole was characterized as stable.

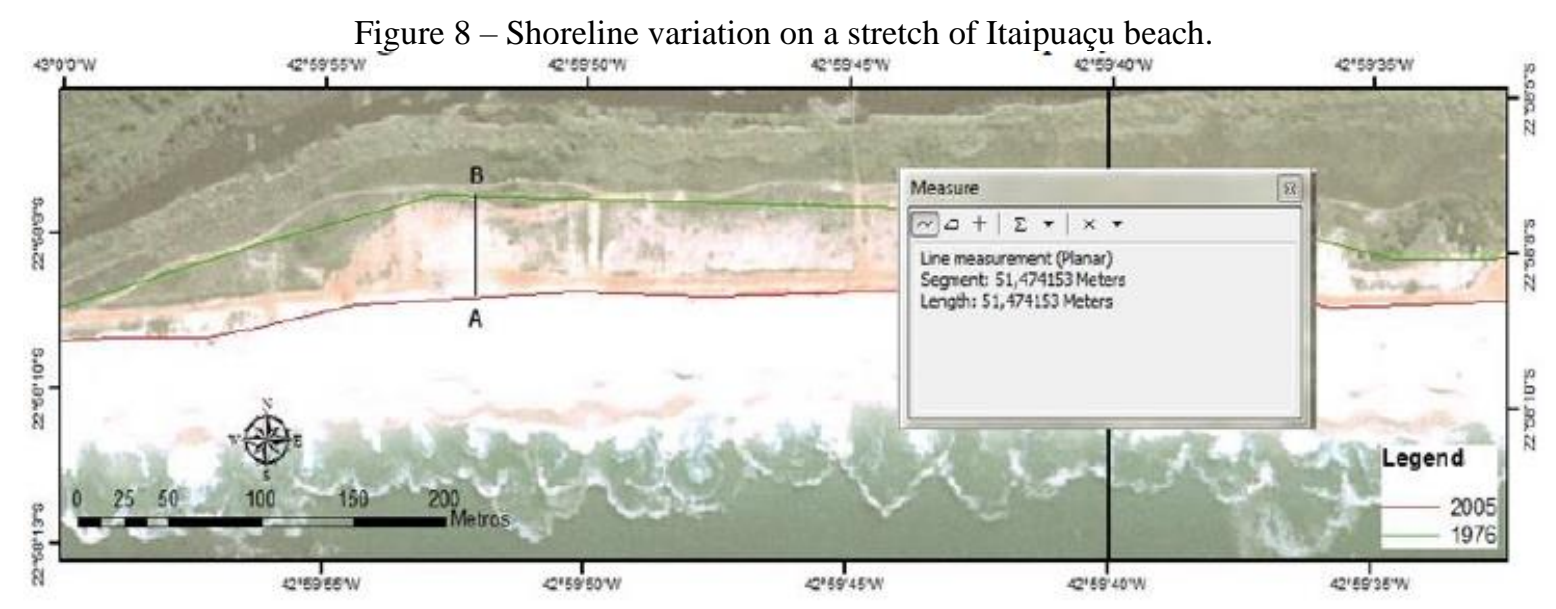

Source: The authors (2020).

Such methodology, however, is not enough, by itself, to establish the erosive pattern of a beach. Aerial photographs of only two dates can hide the behavior of the coastline during the time interval and, depending on the date of acquisition of the photos, they may have been acquired in moments of climatic instability, showing in greater emphasis the loss of land in towards the continent.

It is necessary to use images from different dates together, in addition to monitoring with transversal profiles for the quantification and confirmation of beach erosion.

\subsection{Mean tide range}

The tidal range of the analyzed data showed a maximum variation of 1.4 meters which sets up a system of micro tides. This range to be applied to the Coastal Vulnerability Index is ranked as index $4-$ High (1.0 $1.9 \mathrm{~m})$.

There are two possible interpretations to analyze the tidal data. The first relates to its low amplitude, which can be used as a low vulnerability 91ater following the logic that ocean water reach would be low, due to the momentary advance of sea 91aters occurring in a restricted horizontal space. However, a second reasoning can be used, where the coastal environments that are exposed to micro tides are more vulnerable on the ground that they are not as adapted to flooding, resulting in more serious physical changes. In the analysis of this study, we used the latter interpretation, and considered the Maricá coastline influenced by a micro tide regime has a lower possibility of adaptation to extreme events and rising sea level. Its ecosystem does not have enough adaptations to resist new environmental conditions.

\subsection{Maximum wave height}

The direction and height of waves were analyzed, as well as its frequency (Figure 9). Data refer to the entire city of Maricá, it is not possible to divide them by sector, so that the value found will be applied to all the coast in question. 
Figure 9 - Height and direction and frequency distribution of waves for Maricá.

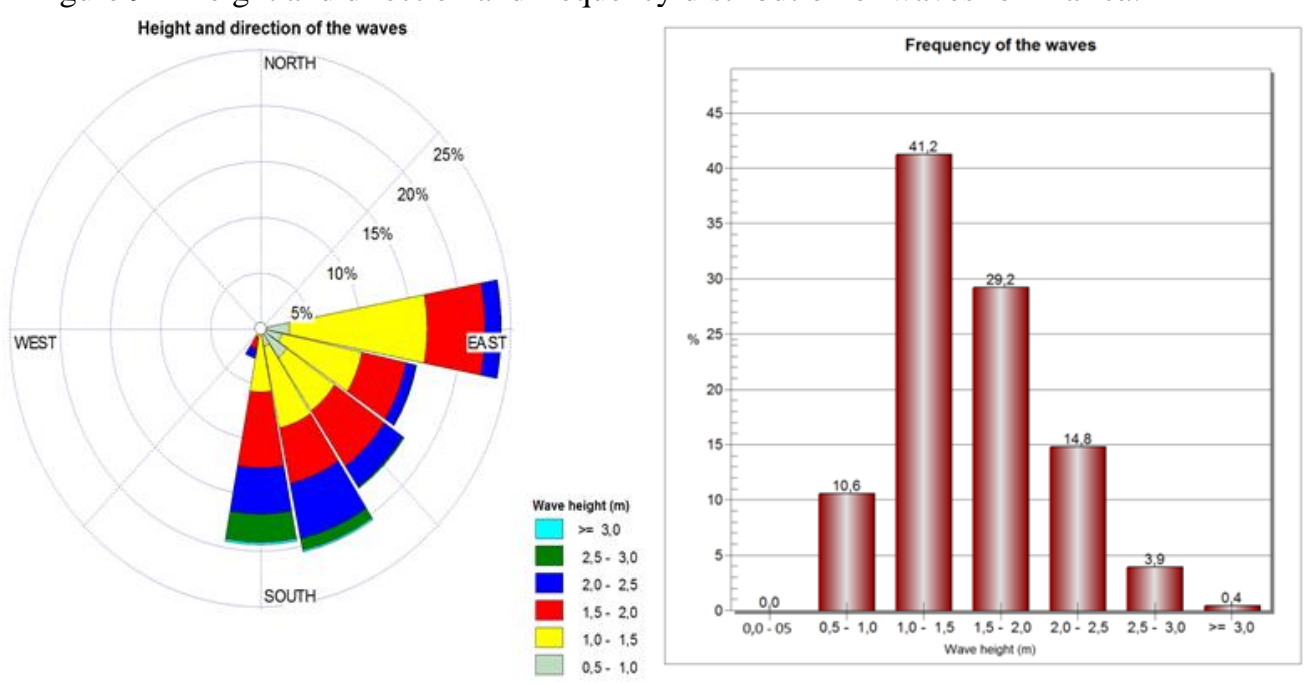

Source: The authors (2020).

The wave data analyzed corroborate the information from Silva, Silva and Santos (2008), especially as southeast waves relate to good weather and south and southwest waves relate to the weather conditions of cold fronts. The minimum value was $0.6 \mathrm{~m}$ and the maximum value was $3.1 \mathrm{~m}$.

Waves between $1.0 \mathrm{~m}$ and $2.0 \mathrm{~m}$ high predominate, confirming the high energy of the coast. The study of wave pattern in the region is critical to the vulnerability classification, since Maricá coastline is characterized by being dominated by waves, which are the main oceanographic agent of environmental change in the study area.

Thus, the coast vulnerability is rated index 5 - Very high (over $1.25 \mathrm{~m}$ ).

\subsection{Dune height}

The city of Maricá has only one dune field that is located in its environmental protection area, the APA de Maricá. This dune field is a fundamental protection for the coastline, setting up a natural barrier against sea water invasion, flooding, wind stress, sediment transport and ocean spray during minor storms, which helps maintain the integrity of the inner part of the coastal system habitat (NORDSTROM, 2008). However, the protective function of this dune The city of Maricá has only one dune field that is located in its environmental protection area, the APA de Maricá. This dune field is a fundamental protection for the coastline, setting up a natural barrier against sea water invasion, flooding, wind stress, sediment transport and ocean spray during minor storms, which helps maintain the integrity of the inner part of the coastal field is threatened due to various environmental impacts caused by human activity: Illegal sand mining, road construction, off-road vehicles travelling over the dunes, irregular dumping of garbage and construction debris (SILVA; ABREU; SILVESTRE, 2012).

The geodetic GPS data collected show a maximum altitude of 10.147 meters in the area close to Barra de Maricá (Figure 10). However, all other points throughout the dune field have elevations below 10 meters. These data differ from that of Silva, Abreu and Silvestre (2012), who identified a maximum height of 12 meters. The dynamics of the wind system allows for periods of greater and lesser amount of sediments depending on the weather, and possible anthropogenic interference with the location could be another cause for such differences.

Therefore, the Maricá dune compartment was rated at two coastal vulnerability indices: CVI 3 Moderate (10 - 20m), next to the urban area of Barra de Maricá, and CVI 4 - High (5 - 10m) for the remaining dune field. The other sectors that do not have dunes were classified with the index 5 - Very High $(0-5 \mathrm{~m})$. The lack of protection in most places causes the coastal system to be quite vulnerable to extreme events, as shown by the final map proposed for this variable. 


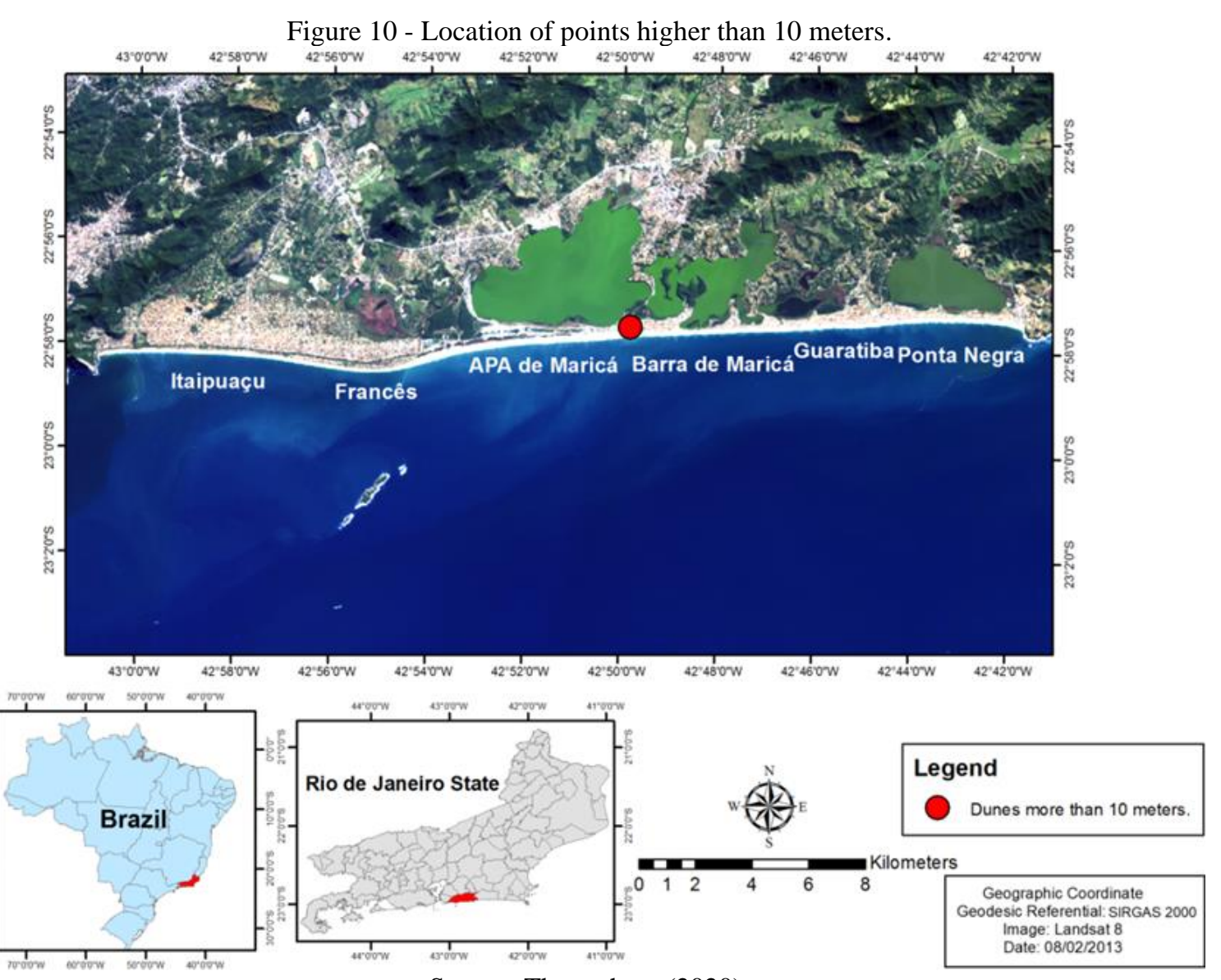

Source: The authors (2020).

\subsection{Urban density}

To establish the coastal vulnerability related to urban occupation, the criterion used was the amount of private and collective households in the city of Maricá (Figure 11), taken from building density, the analysis of census tracts, satellite images and field observations. This criterion links the physical vulnerability to the potential impacts on heavily disturbed areas, indicating a greater or lesser recoverability.

Determining classes with exact figures for the number of households in each index is not simple, since there is no standard number of buildings in a given location to designate a coastline as more or less vulnerable. The best way to score this criterion is to establish classes for each study area, according to quantitative construction data and visual analysis of aerial images in order to establish the building density along the coast. Building numbers are based on census tracts of various sizes, which prevent the determination of numerical classes, once a census tract may have a higher concentration of buildings in a single place, thus influencing other low occupation areas within the tract. Each census sector is represented by an average of constructions on the map of private and collective households, and within this sector there may be areas of higher and lower density. Thus, instead of quantification, a qualitative approach is used for urban area classification, based on available literature.

By analyzing the information obtained, it is clear that theMaricá coastline is already heavily modified, except for one sector: APA de Maricá. By virtue of better preservation, the APA has a lower vulnerability, since the environment has somewhat greater ability to absorb extreme impacts that might occur, besides being subject to potentially lower social and economic losses. Also noteworthy are two small stretches of low vulnerability in Itaipuaçu and Barra de Maricá, due to the proximity of the rocky headlands and the lagoon which hamper urban occupation. Sectors cited above were classified as having a very low vulnerability (CVI $1)$.

A fisherman's community occupies a small strip of coast near the lagoon at the boundary between the sectors of Barra de Maricá and APA de Maricá. Due to the low amount of constructions, this sector was rated with a low vulnerability (CVI 2). This stretch was not rated as a moderate vulnerability, because the houses do 
not take up the entire cross-section of the sand ridge between the beach and the lagoon, as sectors classified elsewhere, and the buildings present an irregular spacing pattern, ensuring a lower density.

Figure 11 - Map of private and collective households in Maricá, RJ.

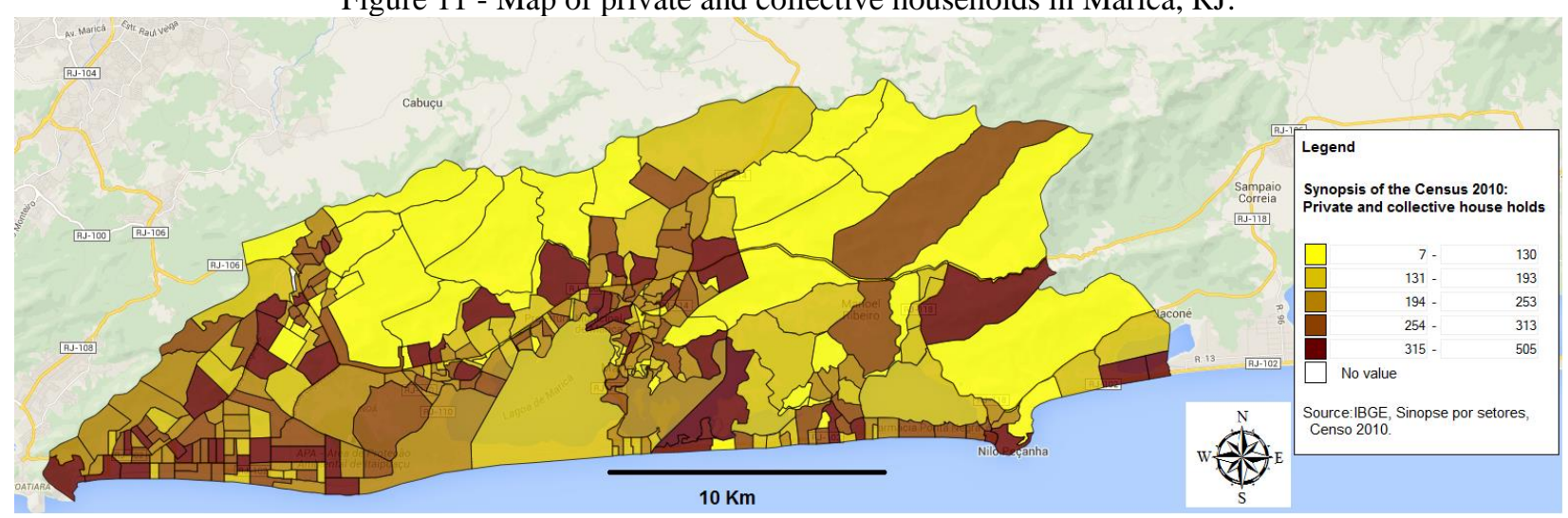

Source: IBGE (2011).

The stretch of coastline referring to the Francês sector was rated a high vulnerability (CVI 4). This interpretation was based on the large number of buildings, although with a lower density than other parts classified as very high vulnerability. This difference can be noticed by the amount of unoccupied spaces between several houses of the place. The possibility of urban expansion in this sector is higher than in other very highly vulnerable sectors because of these still empty spaces.

Finally, the remaining stretches of coastline were classified as with very high vulnerability (CVI 5). Itaipuaçu, Barra de Maricá, Guaratiba and Ponta Negra have a very high urban density, with buildings along the entire cross-section of the coast. In Barra de Maricá, Guaratiba and Ponta Negra, constructions are limited by increased physical barriers, such as a steep topography and / or a lagoon. There are stretches of Itaipuaçu and Francês with more buildings, but with greater spacing between them by virtue of being in a wider area than in Barra de Maricá, Guaratiba and Ponta Negra. The Itaipuaçu sector does not have a lagoon limiting urban sprawl. These are some of the reasons that make it difficult to quantify urban density vulnerability classes based on the number of households in a census tract.

\subsection{Coastal vulnerability}

From the results obtained, we calculated the vulnerability classes for the coast. These classes are based on 25, 50 and 75 percentiles. This approach is used to give a relative value to the equation's absolute numbers, as it is not possible to use numerical vulnerability values to directly compare to other locations. Each vulnerability study that follows this methodology will achieve unique results for each study area. Numerical values obtained for each class may be completely different in other coastal zones. The map below illustrates the spatial distribution of coastal vulnerability along the Maricá shoreline (Figure 12), followed by the occurring percentages of each class (Figure 13), and statistical parameters (Table 6).

Table 6 - Statistical parameters associated with the final results of coastal vulnerability for Maricá.

\begin{tabular}{c|c}
\hline Statistical Parameters & Value \\
\hline Minimum-Maximum & $4.22-84.51$ \\
\hline Mean & 39.22 \\
\hline Median & 31.05 \\
\hline Standart Deviation & 25.09 \\
\hline Percentile 25 & 24.29 \\
\hline Percentile 50 & 44.37 \\
\hline Percentile 75 & 64.44 \\
\hline
\end{tabular}

Source: The authors (2020). 


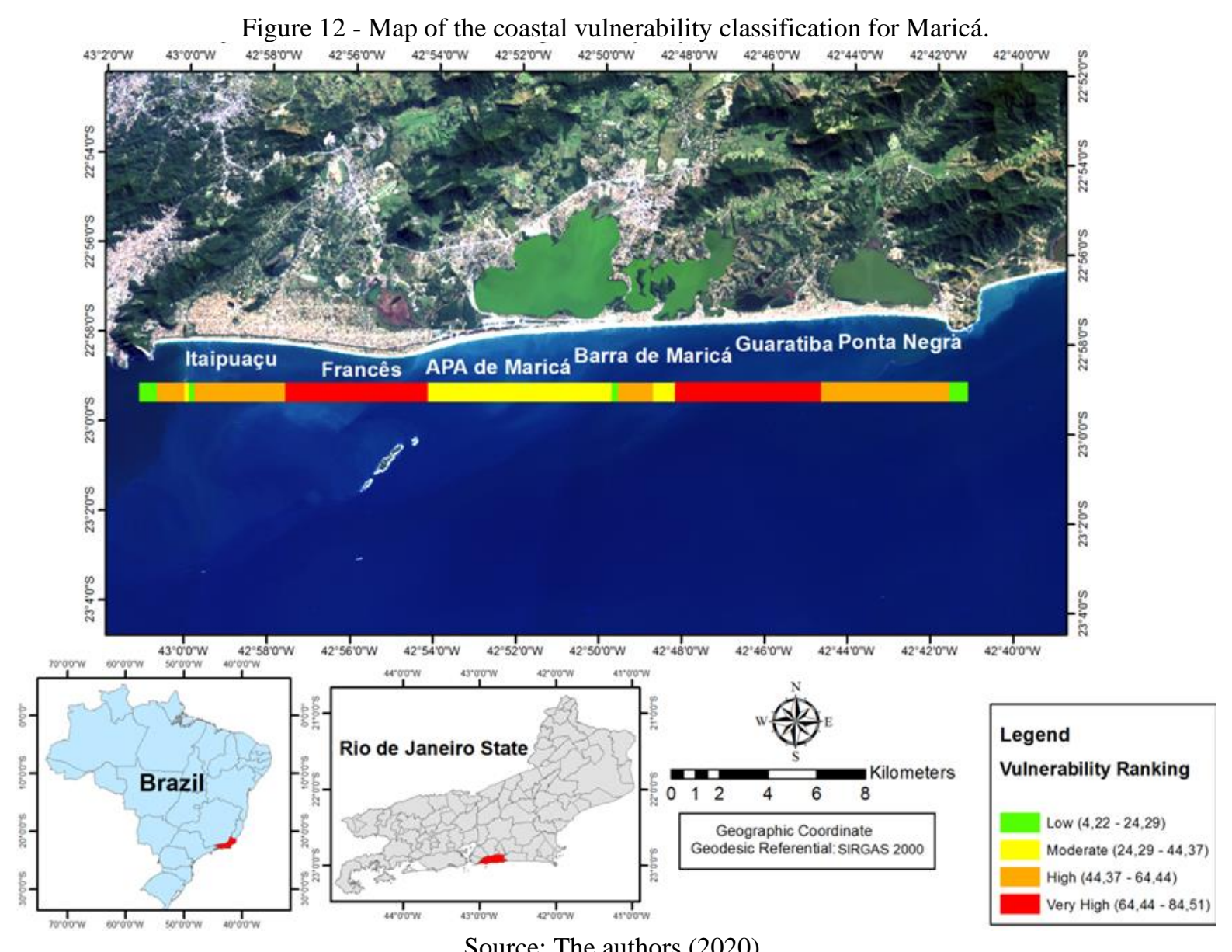

Source: The authors (2020).

Figure 13 -Maricá coastline percentage for each coastal vulnerability class.

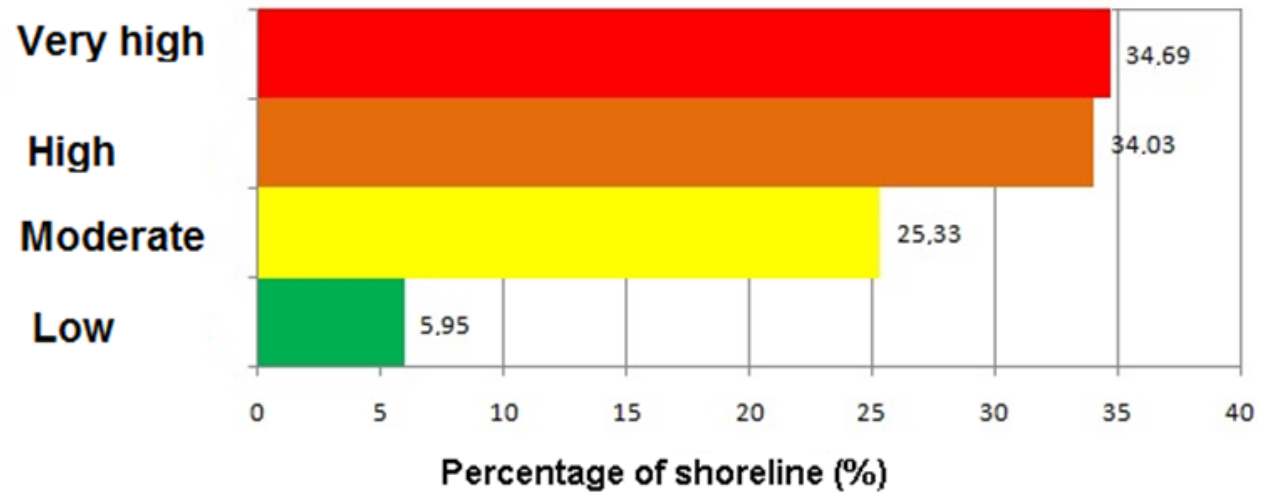

Source: The authors (2020).

By analyzing the results it is seen that about $69 \%$ of the coast has high or very high vulnerability. This result is consistent with previous interpretation of the study area based on field work and in the literature, demonstrating the great energy of the Maricá coastal system, in addition to geological and geomorphological features of the coastline including the low-lying areas of the coastal plain, extremely urbanized at various points; besides being composed mainly of sandy beaches that are easier to be modified by the action of coastal agents.

The numbers show that the square root of the product (calculation used to quantify the CVI) has high values, which are explained by the high vulnerability that some variables provided. The variation in sea level, maximum wave height, geomorphology, urban density and the presence of dunes were classified with the highest vulnerability index for different sectors of the coast, and consequently leveraged the values for each defined class.

The values allow us to conclude that the coast in question, in general, presents a very high vulnerability because the higher the numerical values found, the greater the difficulty of the area to deal with and recover 
with the occurrence of extreme events.

Regarding the spatial distribution of the vulnerability indices, the rocky cliffs of Pedra do Elefante and Ponta Negra are classified as the lowest vulnerability, due to the small likelihood of changes to influence these places, even with the occurrence of extreme events, since they are composed of rocks more resistant to erosion. The Guaratiba and Frances sectors were classified with the highest vulnerability due to the difference in slope values of the coast, which for these sectors are the lowest on the coast. Thus, Itaipuaçu and Ponta Negra, which have higher slope values than the sectors mentioned above, are classified with a high vulnerability index. The APA of Maricá is classified with a moderate index due to the protection of the dunes, which is a variable that no other sector has.

Finally, there are two small stretches of the beach for which the index varies, one in Itaipuaçu and the other between Barra and APA de Maricá. In the first stretch, the variation in the vulnerability index between low and very low refers to the variation of the coastline, as in the part classified as of low vulnerability, a progradation of the coastline was identified, thus decreasing its index. In the second section, the small portion of the coast classified with the low vulnerability index is explained by the presence of dunes over 10 meters high, increasing the protection of the coast and making the section less vulnerable. In the west direction, the stretch of the APA of Maricá continues with a moderate index, since the dunes decrease in height and, consequently, reduce the protection of the coast. In the eastern direction, the Barra de Maricá section presents greater vulnerability, as there are no dunes and the urban density is very high, increasing the index value for the location. Continuing in an easterly direction, still in Barra de Maricá, a small section was classified with moderate vulnerability due to the absence of constructions, as it concerns a space in which the lagoon almost comes into contact with the ocean, being separated by a small beach ridge, which can be opened in the event of an increase in the level of the lagoon so that the transport of this volume of water towards the ocean occurs, avoiding possible flooding in urbanized stretches.

\section{CONCLUSION}

The coastal vulnerability mapping of Maricá is an important tool for urban planning and coastal management in the region. However, this study does not represent, in essence, the solution to the various situations found throughout the region. Therefore, other actions to increase the quality of coastal management are recommended: the use of data on the largest possible scale; additional biological, economic and social studies; environmental monitoring programs; preservation of protected areas; monitoring of urban expansion; integration between the university and the government to increase the number of studies; environmental education programs for public awareness.

The areas of the Maricá coastline most vulnerable to extreme events and rising sea level have been identified from the mapping carried out. An order of priorities, identifying critical sectors along the coastline that deserve concentrated action is easily identified. Urban occupation is one of the most critical factors for the high vulnerability index of the Maricá municipality. The profound modification of the natural environment by man hinders coastal system recoverability and the increases the potential for economic damage.

\section{Acknowledgments}

Special thanks are due to Prof. Alberto Luís da Silva (UFF), for his help with the processing of GPS data. Thanks are also to PROAP - UFRJ (Programa de Apoio à Pós-Graduação) from the Geology Graduate Program, PPGL - UFRJ, for financial support for fieldwork. The authors wish to express their gratitude towards the editors, João Vitor Meza Bravo and Tulio Alves Santana, for their dilligent work, as well as the anonymous reviewers, for improving the original manuscript.

\section{Authors' Contributions}

Conceptualization, formal analysis, investigation, methodology, project administration, resources, software, validation, visualization and writing (review and editing) were carried out by all authors. Data curation and writing (original draft) were under the responsibility of Osilieri. The supervision was carried out 
by Seoane and Dias, while the funding acquisition was directed by Seoane.

\section{Conflict of Interest}

The authors declare no conflict of interest.

\section{References}

ABUODHA, P; WOODROFFE, C.D. Assessing vulnerability of coasts to climate change: A review of approaches and their application to the Australian coast. In: WOODROFFE C.D.; BRUCE, E.; PUOTINEN, M.; FURNESS R.A. (Ed.).GIS for the Coastal Zone: A selection of Papers from Coast GIS 2006. Wollongong: Australian National Centre for Ocean Resources and Security, 2007.p. 458.

CARUSO JÚNIOR, F.; CUNHA, H.C.S.; DIOS, F.R.B. Cenozóico/Quaternário. In: SILVA, L.C. (ed.); CUNHA, H.C.S. (Ed.). Geologia do Estado do Rio de Janeiro. Brasília: CPRM, 2001. p. 69-75.

DEVOY, R.J.N. Coastal vulnerability and the implications of sea-level rise for Ireland. Journal of Coastal Research, Coconut Creek, v. 24, n. 2, p. 325-341, 2008.

DIRETORIA DE HIDROGRAFIA E NAVEGAÇÃO (DHN). Carta Náutica 1506: Proximidade da Baía de Guanabara. Disponível em: http://www.mar.mil.br/dhn/chm/box-cartas-raster/raster_disponiveis.html . Acesso em:Ago. de 2018.

DOLAN, A.H.; WALKER, I. J. Understanding vulnerability of coastal communities to climate change related risks. Journal of Coastal Research, CoconutCreek, v. SI 39, p. 1316-1323, 2006.

EMPRESA BRASILEIRA DE PESQUISA AGROPECUÁRIA (EMBRAPA). Sistema brasileiro de classificação de solos. Brasília: Serviço de Produção de Informação, 1999.

FORÇA AÉREA BRASILEIRA (FAB). Mosaico de fotografias aéreas do município de Maricá. Rio de Janeiro, 1976. Escala 1:20000.

FRAZIER, T.G.; WOOD, N.; YARNAL, B.; BAUER, D.H. Influence of potential sea level rise on societal vulnerability to hurricane storm-surge hazards, Sarasota, Florida. Applied Geography, Amsterdam, v. 30, p. 490-505, 2010. DOI: https://doi.org/10.1016/j.apgeog.2010.05.005

GORNITZ, V. M.; White, T. W. A coastal hazards database for the U.S. East coast. Oak Ridge: Oak Ridge National Laboratory, 1992.

INSTITUTO BRASILEIRO DE GEOGRAFIA E ESTATÍSTICA (IBGE). Metadados do produto Modelo Digital de Elevação 1:25000 do Projeto RJ - 25. Rio de Janeiro: Diretoria de Geociências, 2005.

INSTITUTO BRASILEIRO DE GEOGRAFIA E ESTATÍSTICA (IBGE). Malha Municipal Digital de Setores Censitários do Censo de 2010. 2011. Disponível em: <http://www.censo2010.ibge.gov.br/sinopseporsetores/?nivel=st>, acesso em:Set. de 2018.

INTERGOVERNMENTAL PANEL ON CLIMATE CHANGE (IPCC). Climate Change 2007: The Physical Science Basis. Contribution of Working Group I to the Fourth Assessment Report of the Intergovernmental Panel on Climate Change. Solomon, S., D. Qin, M. Manning, Z. Chen, M. Marquis, K.B. Averyt, M. Tignor and H.L. Miller (Ed.).Cambridge: Cambridge University Press, 2007.

LINS-DE-BARROS, F.M. Risco, vulnerabilidade física à erosão e impactos socio-econômicos na orla urbanizada do município de Maricá, Rio de Janeiro. Revista Brasileira de Geomorfologia, Brasília, v.6, n. 2, p. 83-90, 2005. DOI: http://dx.doi.org/10.20502/rbg.v6i2.54

MARINHA DO BRASIL. Centro de Hidrografia da Marinha. Estações maregráficas. Rio de Janeiro, 2010. Disponível em: <https://www.marinha.mil.br/chm/sites/www.marinha.mil.br.chm/files/dados_de_mare/50140__ilha_fiscal_f-41_-_tabuas_padrao_v1-10_0.pdf>. Acesso em: 10 jan. 2019.

MOLION, L.C.B. Aquecimento Global: uma visão crítica. Revista Brasileira de Climatologia, Curitiba, vol. 3/4, p. 7-24, 2008. DOI: http://dx.doi.org/10.5380/abclima.v3i0.25404 
MUEHE, D.; VALENTINI, E. O Litoral do Estado do Rio de Janeiro: uma caracterização físicoambiental. Rio de Janeiro: Femar, 1998.

MUSEKIWA, C.; CAWTHRA, H.C.; UNTERNER, M; VAN ZYL, F.W. An assessment of coastal vulnerability for the south african coast. South African Journal of Geomatics, Cape Town, v.4, n. 2, p.123-137, 2015. DOI: http://dx.doi.org/10.4314/sajg.v4i2.5

NORDSTROM, K.F. Beach and Dune Restoration. New York: Cambridge University Press, 2008.

PALMER, B J.; VAN DER ELST, R.; MACKAY, F.; MATHER, A A.; SMITH, A M.; BUNDY, S C.; THACKERAY, Z.; LEUCI, R.; PARAK, O. Preliminary coastal vulnerability assessment for KwaZuluNatal, South Africa. Journal of Coastal Research, Coconut Creek, vol. 64, p.1390-1395, 2011.

PATERSON, N.R. Global warming: A critique of the antropogenic model and its consequences. Geoscience Canada, ST. John's, v. 38, n.1, p. 41, 2011.

PILKEY, O.H.; DAVIS, T.W. An analysis of coastal recession models, North Carolina coast. In: NUMMEDAL, D.; PILKEY, O.H.; HOWARD, J.D. (Ed.).Sea-level Fluctuation and Coastal Evolution. Tulsa: SEPM (Society for Sedimentary Geology) Special Publications, 1987. p. 59 - 68.

SILVA, A.L.C.; ABREU, M.L.L.; SILVESTRE, C.P. Dunas costeiras na barreira arenosa holocênica da APA de Maricá no Estado do Rio de Janeiro. Revista Geo Norte, Manaus, v. 2, n. 4, p. 367-376, 2012.

SILVA, L.C; DEHLER, N.M. Meso/Neoproterozóico. In: SILVA, L.C.; CUNHA, H.C.S. (Ed.). Geologia do Estado do Rio de Janeiro. Brasília: CPRM, 2001. p. 21-29.

SILVA A.L.C.; SILVA, M.A.M; SANTOS, C.L. Comportamento morfológico e sedimentar da praia de Itaipuaçu (Maricá, RJ) nas últimas três décadas. Brazilian Journal of Geology, São Paulo, v. 38, n.1, p. 89-99, 2008.

SILVA, L.C.; VIEIRA, V.S.; GUIMARÃES, M.T.; SOUZA, E.C. Neoproterozóico/Cambriano. In: SILVA, L.C.; CUNHA, H.C.S. (Ed.).Geologia do Estado do Rio de Janeiro. Brasília: CPRM, 2001. p. 31-53.

SZLAFSZTEIN, C.; STERR, H. A GIS-based vulnerability assessment of coastal natural hazards, State of Pará, Brazil. Journal of Coastal Conservation, Dordrecht, v. 11, n.1, p. 53-66, 2007. DOI: https://doi.org/10.1007/s11852-020-00733-z

THIELER, E. R.;Hammar-Klose, E. S. National assessment of coastal vulnerability to sea level rise, Preliminary Results for the U. S. Atlantic Coast. Massachusetts: U. S. GeologicalSurvey, 1999. Disponível em: http://pubs.usgs.gov/of/1999/of99-593/. Acesso em: Jun. de 2018.

TOLMAN, H. L. User manual and system documentation of WAVEWATCH-III version 3.14.Camp Springs: National Centers for Environmental Prediction, 2009.

TRAN, L.T.; O’NEILL, R.V.; SMITH, E.R. Spatial pattern of environmental vulnerability in the Mid-Atlantic region, USA. Applied Geography, Amsterdam, v.30, p. 191-202, 2010. DOI: https://doi.org/10.1016/j.apgeog.2009.05.003

ZOU, L.; THOMALA, F. The causes of social vulnerability to coastal hazards in southeast Asia. Stockholm: Stockholm Environment Institute, 2008. 


\section{Lead Author Biography}

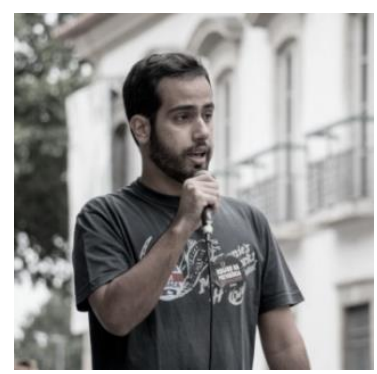

Paulo Renato Gomes Osilieri, Rio de Janeiro, 1990. Degree in Geography from Universidade Federal Fluminense - UFF (Niterói - RJ), Specialist in Quaternary Geology from the Museu Nacional (Rio de Janeiro - RJ) and Master in Geology from the Universidade Federal do Rio de Janeiro - UFRJ (Rio de Janeiro - RJ). He has experience in the areas of coastal geology and geomorphology, remote sensing, geoprocessing, with an emphasis on coastal erosion studies, coastal management and geotechnologies applied to quaternary sedimentation environments. He is currently a volunteer researcher at the Photogeology Laboratory at UFRJ and at the Coastal Studies Center at UFF.

Esta obra está licenciada com uma Licença Creative Commons Atribuição 4.0 Internacional - CC BY.Esta licença permite que outros distribuam, remixem, adaptem e criem a partir do seu trabalho, mesmo para fins comerciais, desde que lhe atribuam o devido crédito pela criação original. 